\title{
Creativity: Cultural Capital in the Mathematics Classroom
}

\author{
Rae Ann Hirsh \\ Carlow University, Pittsburgh, USA. \\ Email: rahirsh@carlow.edu \\ Received August 28 $8^{\text {th }}, 2010$; revised October $2^{\text {nd }}, 2010$; accepted October $10^{\text {th }}, 2010$.
}

\begin{abstract}
Contemporary students face unique economic, environmental, and humanitarian challenges. The problem solving required to address these challenges requires solutions that have never been thought of before. In order to tackle these problems, teachers must challenge the traditional problem solving methodologies used in math classes and encourage new problem solving strategies through incorporation of the arts and facilitating of creative problem solving. This article will explore the research surrounding creativity, the arts, and creative problem solving and suggest future applications of creativity in the mathematics classroom.
\end{abstract}

Keywords: Creativity, Math, Problem Solving, Arts, Curriculum, National Council for the Teaching of Mathematics

\section{Introduction}

Memories of past math classes are filled with algorithms, worksheets, tests, and memorization. Math activities consisted of timed multiplication tests, working out algorithms on the chalkboard, and following teacher-given directions. Math was often thought of as memorization of facts and algorithms. Many math textbooks, workbooks, and resources reinforced this traditional memorization methodology. While this type of math instruction may have had its place in the past, contemporary math instruction should reflect society's growing need for advanced problem solving skills to deal with current and future economic, humanitarian, and environmental challenges. This paper will challenge the traditional math methodology and investigate the use of creativity in problem solving to deal with contemporary challenges. The research will define creativity and the creative process; illustrate ways creativity can be incorporated into the math curriculum through the arts; explore creative problem solving; and suggest future applications of creativity in the mathematics class-room.

\section{Creativity: A New Direction for Mathematics Instruction}

Contemporary views of creativity recognize it as the "cultural capital of the twenty-first century" (Sheridan-Rabideau, 2010), for it is "among the most important and pervasive of all human activities" (Simonton, 2000). Creativity invites experimentation, formulation of new hypotheses, and opens possibilities. Creativity involves personality, affect, motivation, culture, potential, and beliefs (Ivcevic, 2009). With so many variables, the definition of the word itself is quite elusive (Hope, 2010). However, creativity is more easily defined when it is specific in its application (Hope, 2010). For example, when creativity is associated with art, poetry, or music, the definition becomes clearer. In addition to the application, creativity requires the work of others who support or use the creative work (Hope, 2010). From these perspectives, creativity is the ability to respect and transcend rules in order to cause a change or create a product that is valued, appreciated, and or used (Isenberg \& Jalongo, 2010; Gardner, 2006). Creativity is a necessary and vital tool for dealing with the economic, environmental, and humanitarian challenges of the 21 st century (Sheridan-Rabideau, 2010) and helps prepare children for the real world (Sternberg, 2006). Creativity is a basic requirement that is highly respected and valued in most disciplines and professions (Gardner, 2009; Christensen, Johnson, \& Horn, 2008).

With this in mind, one would expect creativity to be nurtured and encouraged in the school environment. Unfortunately a skills-based emphasis continues in contemporary schooling in favor of more direct instruction of math and reading skills (Gardner, 2006). Traditional math instruction has been devoid of methodologies that encourage creativity. In contemporary society, members have access to facts and algorithms through calculators, computers, and other tools. While understanding facts and algorithms is important to foundational math skills, applying, using, and creating from these skills becomes more accessible through the tools available. The potential for math application and problem solving has increased and encourages a different definition of mathematical ability. Gardner (Gardner, 1993) describes logical/mathematical intelligence as the "ability to recognize significant problems and then to solve them." This definition challenges the 'follow an algorithm' definition of math that many school students have (Tsao, 2005) and encourages creativity in the problem solving process through encouraging the identification and solution of significant problems. Creativity is a necessary tool for brainstorming, strategizing, and solving problems (Wallace, Abbott, \& Blary, 2007). Creative problem solving can be developed through integration of the arts and student-led problem solving strategies.

\section{The Arts: Subjects Left Behind}

With the contemporary emphasis on testing and standards, less time in the classroom is dedicated to the arts and more time is dedicated towards math and reading. No Child Left Behind (2000) is an education law enacted to help all children become proficient in reading and writing. Unfortunately, the No Child 
Left Behind Act (2000) has turned into "subjects left behind" (National Education Association, 2004). More time is spent on reading and math and less time dedicated to the arts. In some schools, arts have been eliminated to allow more time for reading and math remediation (National Education Association, 2004). This unfortunate trend has further isolated many students from developing their full mathematical potential. It may be the artistic endeavors that encourage or help to develop math ability. Artistic development is an integral part of math (Wilson, 2009), and math is an integral part of artistic development (Schattschneider, 2006).

The arts, which include music, movement, art, and drama, significantly contribute to mathematical understanding and application (Wilson, 2009; Schattschneider, 2006; Gardner, 2006; Jensen, 2005). Children display different levels of creative talent in the arts which include technical skill, visual thinking, and creativity (Wilson, 2009). Technical skill in the arts is demonstrated by "the ability for students to manipulate materials to convey an intended purpose" (Wilson, 2009). Teachers can take advantage of this definition by allowing students the opportunity to draw pictures to solve problems, use graphic organizers, offer a choice of mathematic expression, and by providing opportunities to present information visually (Wilson, 2009). Visual thinking is "the ability of people to understand and interpret visual information" (Wilson, 2009). Teachers can tap into this method of learning through inviting children to create storyboards to illustrate steps to an algorithm, organizational charts, visual story problems, and other visual representation of math concepts (Wilson, 2009). Figure 1 demonstrates a kindergarten student's ability to visually demonstrate a problem solving strategy.

The student was playing in the doll corner. She had four dolls and twelve cookies. Her teacher asked her how she would divide the cookies equally amongst the dolls. The student had a difficult time explaining and thinking of a strategy. Her teacher encouraged her to draw her strategy and she was able to solve the problem through the visual representation (See Figure 1).

Creativity in the arts is "the ability of students to think flexibly and generate novel ideas" (Wilson, 2009). Teachers can take advantage of creativity in students through allowing brainstorming sessions, attribute listing, and through encouraging multiple problem solving perspectives (Wilson, 2009). Technical skills, visual thinking skills, and creativity in music, art, and movement can be infused into the mathematics classroom to

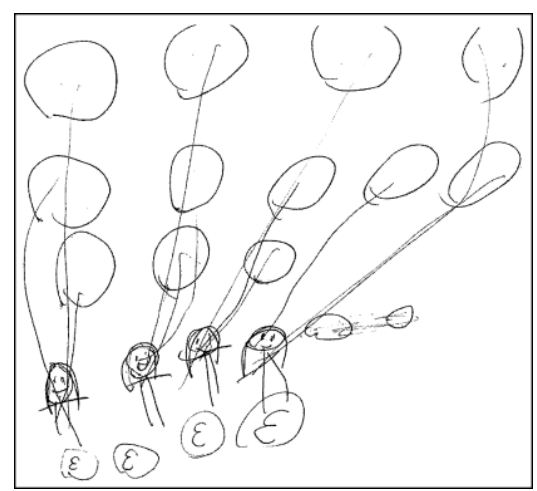

Figure 1.

Kindergarten division. help more children reach their full mathematical potential. Specific arts, such as music, art, and movement, can offer key entry points into math lessons, and provide opportunities to develop, explore, and assess math skills (Gardner, 2006).

\section{Music and Art: Contemporary Tools for Mathematic Success}

Music and art, although overlooked, are necessary components of the contemporary curriculum that contribute to the development of mathematical knowledge and understanding (Sloboda, 2001). Musical tasks offer the student the opportunity to develop concepts of number through beat, rhythm, tempo, time, and scale (Harris, 2008; Hardesty, 2008). An understanding of music provides a foundation for the mathematical understanding of frequencies, geometric progressions, ratios, and proportions (Harris, 2008). Music helps build a foundation in young children for spatial-temporal reasoning (Harris, 2008; Royal, 2007) and is related to higher math achievement test scores (Rauscher, 1998). Movement encourages exploration of time, measurement, number, rhythm, and placement. To some students, mathematical knowledge doesn't make sense in its traditional realm, but understanding unfolds when applied in different activities and domains (Hirsh, 2004).

Art can provide teachers with specific strategies that may help a child understand math concepts. Spatial strategies may include charts, tessellations, geometrical grids, graphs, logic puzzles, flip charts, origami, information tables, and games (Wilson, 2009). These strategies take advantage of artistic strengths and interests and present mathematic concepts in a more accessible (Wilson, 2009).

Gabi, a third grade student, completed a unit on geometry. For her comprehensive test, her teacher took advantage of her interest in dogs and art. Her task was to design a theme park for puppies. The theme park incorporated the mathematical terminology, concepts, and reasoning of the unit and met the math geometry, trigonometry, and problem solving standards through the various design tasks such as Geometric German Shepherd cups, Rover Roller Coaster, Congruent Café, and the Puppy Treat Box.

In designing the various attractions at the theme park, Gabi needed to be able to identify, visually represent, problem solve, and apply the knowledge of the geometry unit through her artistic design of the theme park (See Figures $2 \& 3$ ).

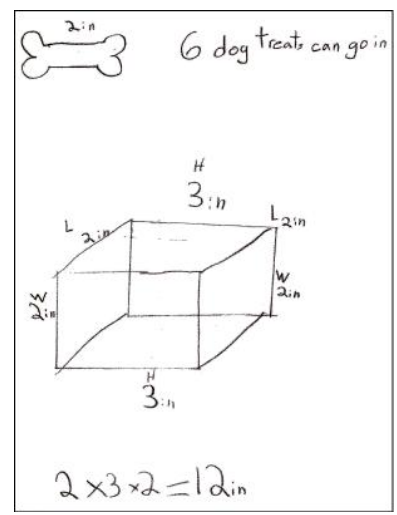

Figure 2.

Dog treat container. 


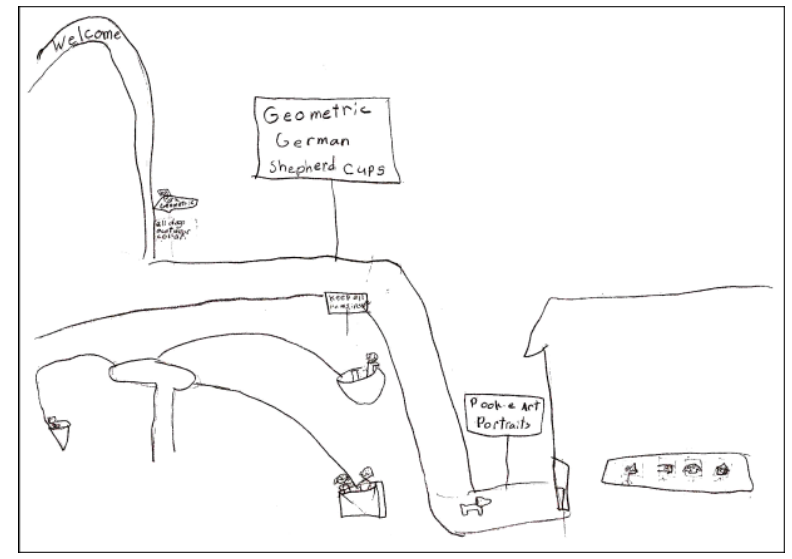

Figure 3.

Geometric german sheppard cups.

In contrast, the unit test was a multiple choice test that required knowledge of terminology. In using the unit test, her teacher would have missed an opportunity for Gabi to demonstrate an advanced ability to apply the mathematic concepts and problem solve.

While art can be a tool for the development of math skills, math can be a tool in the creation, analysis, and teaching of art (Schattschneider, 2006). Math is used in the creation of art through the use of fractals and algorithms. Patterns, sequences, and ratios can be discovered in works of art. Math vocabulary can be used to analyze art and help to define cultural and artistic preferences and patterns (Schattschneider, 2006). Math can be used to teach art as students study perspective, create designs, solve puzzles, and study formulas (Schattschneider, 2006).

A fourth grade student, Tori, was having a difficult time memorizing her multiplication tables. It was difficult for her to see the patterns in the numbers. She did, however, have advanced art ability. Her teacher decided to take advantage of that ability and had her construct a multiplication board out of nails and wood. The board is represented in Figure 4. After constructing the board, the student used string to represent each of the multiplication facts. Visual patterns emerged from this experience. The student recorded the patterns in a notebook and began to understand the mathematic patterns presented in this visual form (Figure 5). She then was able to understand and recall her multiplication tables. This method was inspired by the Waldorf philosophy.

Waldorf education infuses music and art with all core subjects (Steiner, 1996). Students produce their own textbooks and create elaborate pictorial representations of math concepts such as multiplication, geometry, banking, and detailed physics applications. Eurhythmy is another music/movement-based strategy Waldorf teachers use. Eurhythmy encourages rhythmic movement, chants, and music to facilitate the development of language and mathematic skills (Steiner, 1996). Students often discover patterns in number ranging from skip counting to the Fibonacci number sequence in eurhythmic activities. Waldorf students are typically advanced in mathematical understanding and application in comparison to their non-Waldorf peers by the end of $8^{\text {th }}$ grade (Oberman, 2008).

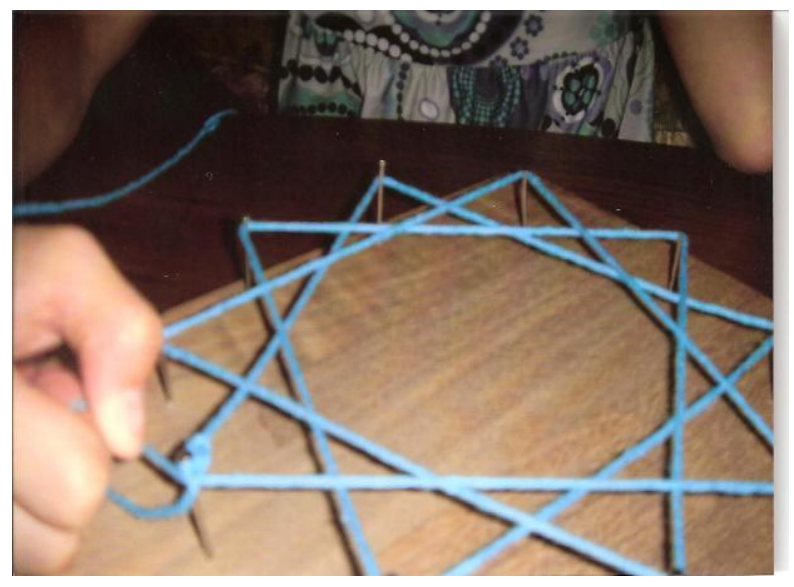

Figure 4.

Multiplication board.

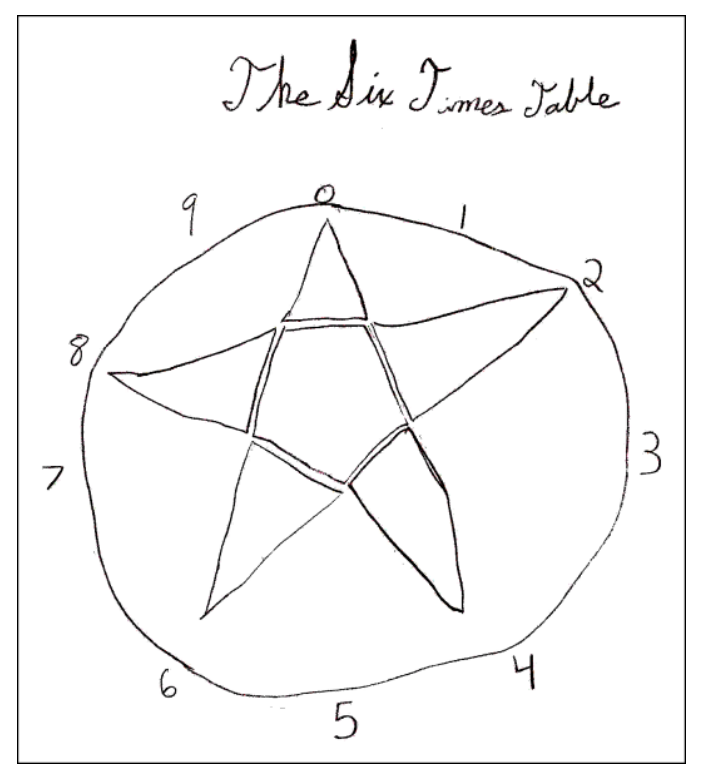

Figure 5.

Drawing of multiplication board.

\section{The Movement Arts: More Subjects Left Behind}

Time for movement in the classroom has been diminishing. Recess and physical education have been replaced with teacherstructured academic tasks.

Movement in other classes during the school day is very limited. However, movement offers unique problem solving opportunities for the math student. Movement in the arts involves gross and fine motor manipulation and (Gardner, 2006). These bodily/kinesthetic arts "contribute to the development and enhancement of critical neurobiological systems, including cognition, emotions, immune, circulatory, and perceptual-motor skills" (Jensen, 2005). These arts improve timing, coordination, motivation, and attention (Hirsh, 2004). Children labeled with various disabilities often move, fidget, touch things, and get out of their seats. While some see this as misbehavior, other teachers can use this as an opportunity to take advantage of the need 
to move in the mathematics classroom (Armstrong, 2010). Movement can be accessed in the classroom through three distinctive realms: industrial, recreational, and dramatic (Jensen, 2005).

Industrial arts refer to skills often thought of as trade work such as woodworking, sculpting, design, basket weaving, and graphic arts (Hirsh, 2004). This type of art requires a specific skill set, yet the different types of industrial arts rely heavily on the same set of math skills to be successful. Proportion, measurement, geometry, ratios, formulas, material analyses, and number concepts are all necessary skills in industrial design and work. The industrial arts can be useful motivators for applying and understanding math concepts.

Jason was a sixth grade student who had difficultly with many math concepts, but displayed exceptional skill in the industrial arts. During a measurement unit, Jason's teacher assigned him a different task as an alternative to a math exam. He was to design and build a small bench for the classroom. His teacher provided him with measurement specifications, the wood, and measuring devices. Jason drew his design, had it approved by this teacher, and then began to measure, cut, and sand the wood. He assembled the bench and his teacher used a rubric for assessment. When Jason reviewed the rubric, he exclaimed that he had no idea that he was that smart. When Jason saw how his industrial art skills were related to math concepts, his confidence in problem solving in the classroom improved and so did his math skills.

Recreational arts include participation in gross motor activities for enjoyment (Jensen, 2001). These activities may include exercise, games, obstacle courses, and sports. The distinctive attribute of recreational arts is the essence of recreation or free choosing of the activity. Recreational arts can be incorporated into the mathematics classroom through scavenger hunts, sport-related activities, games, and obstacle courses. Scoring, calculation, timing, measurement, trajectory, speed, specific skill games, and activities can be used to capture the interest and motivation of otherwise disinterested students.

One disinterested student was John. He was a seventh grade student struggling with traditional math. At lunch, a debate broke out among students about the effectiveness of Gatorade on sports performance. John was particularly interested. During math class, John's teacher asked him if he would like to design an experiment that would test his hypothesis of the effectiveness of Gatorade. John expressed great enthusiasm for the project and designed several recreational sport activities that would be used in the experiment. He had volunteers try each activity with and without Gatorade. He recorded all the data which included scoring, timing, measurement, speed, and various calculations. In math class, John would usually give up quickly if the calculations and data were challenging. However, he was determined to test his hypothesis and his perseverance was greatly enhanced in this situation. After analyzing the data, he came to the conclusion that Gatorade did not help sports performance and presented his findings to the class. His interest in recreational arts contributed to a successful application of math skills.

Dramatic arts involve dance, drama, role play, and (Jensen, 2001). Dance allows the opportunity to develop beat, rhythm, tempo, time, measurement, and problem solving which are foundational problem solving math skills. Through drama, mathematical concepts can be explored, developed, and commu- nicated. Students can create body sculptures of geometric shapes and act out scenarios that demonstrate area, perimeter, and volume. Role play provides an opportunity to dramatize problem solving strategies.

A group of older students had the task of designing a math game for kindergarten students. They had to incorporate concepts of number and counting in the game. They decided to create a life-size game board (See Figure 6). The kindergarten students were to be the game pieces. The spaces on the game board had different addition story problems written on them and would have to be acted out if landed upon. A box of props was next to the game board. A giant die was created out of a cardboard box. Kindergarten students took turns throwing the die and then walking that number of spaces on the game board. When they landed on a space, they would need to act out the addition story problem using the props in the box. The kindergarten students were very excited to participate in the game and came up with additional story problems for the game in class after the experience was over. The new story problems were creative and involved different thinking processes than the original problems.

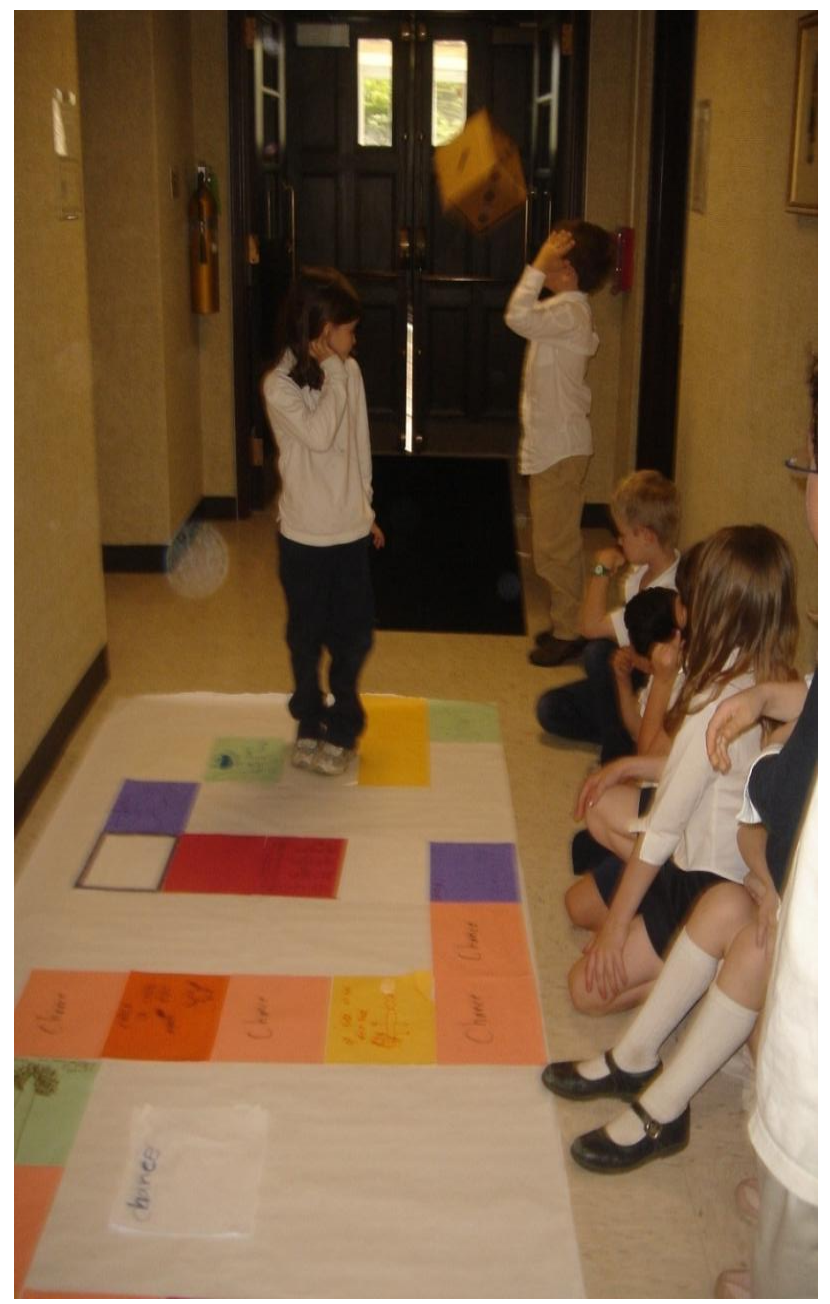

Figure 6.

Life-Size game board 


\section{Creativity: Problem Solving in the Twenty-First Century}

Albert Einstein stated that "we can't solve problems by using the same kind of thinking we used when we created them." These profound words express the critical importance of nurturing creative problem solving skills in children. Creative problem solving is useful in most vocations. For example, in business, creativity can disrupt the normal trajectory of product development to inspire a new product or technology (Christensen, Johnson, \& Horn, 2008); in literature, creativity is recognized and valued through awards, book sales, and impact; and in sales, successful salespeople need innovative techniques and strategies to compete for customers. Thinking outside-the-box produces new and improved products, materials, and services and is valued in most professions.

Traditionally, students in math classes are presented with an algorithm, encouraged to follow the algorithm step by step, and produce a correct answer. This process negates the student's responsibility of brainstorming, creating, producing, and strategizing solutions to problems (Gardner, 2006). In school, the situations for applying algorithms are controlled. Out of school, those situations are not controlled and algorithms may not be applicable or useful for dealing with real-world problems.

The traditional approach to math is evidenced in conversations with elementary school students. A group of elementary school students were interviewed about their thoughts and feelings of math class (See Table 1). A common theme appeared. Students expressed concerns about testing. The student with the highest grades in math stated she knew a lot more than the test showed. Students with the lowest grades believed the tests contained new material and they were not able to remember the correct algorithm when the problems were mixed together. All students believed that success in math was equated with the ability to follow an algorithm and arrive at a correct answer. When students had something that was difficult in math, parents or teachers would reiterate the algorithm. Often, this was confusing for the students with the lower grades, if they didn't understand it the first time, saying it again did not help them either. Most of the students did not enjoy math class unless games, art, or other activities were involved.

Table 1.

Student mathematics questionnaire.

\begin{tabular}{|c|c|c|c|c|c|}
\hline Student & $\begin{array}{l}\text { What grades do you } \\
\text { have in math? }\end{array}$ & Do you like math in school? & $\begin{array}{l}\text { How do you solve math } \\
\text { problems in school? }\end{array}$ & $\begin{array}{l}\text { What happens if you } \\
\text { don't understand it? }\end{array}$ & $\begin{array}{c}\text { Do you think tests you have } \\
\text { in school show what you } \\
\text { have learned? }\end{array}$ \\
\hline Student 1 & $A$ & $\begin{array}{l}\text { I sometimes like math games. } \\
\text { When we used art and games to } \\
\text { learn it, I really liked it. I found } \\
\text { math really easy. }\end{array}$ & $\begin{array}{l}\text { I do the problem step by } \\
\text { step until I know the } \\
\text { whole lesson. My teacher } \\
\text { tells me the steps to follow. }\end{array}$ & $\begin{array}{l}\text { I ask my teacher and she } \\
\text { tries to help me by telling } \\
\text { me what I did wrong. }\end{array}$ & $\begin{array}{l}\text { I really think that the teacher } \\
\text { would know better than the } \\
\text { test or other work. Sometimes } \\
\text { test shows them, but not all } \\
\text { the time. I knew more than } \\
\text { what was on the test. }\end{array}$ \\
\hline Student 2 & $A$ 's \& $B$ 's & $\begin{array}{l}\text { Yes, I liked math class when } \\
\text { I played games like around the } \\
\text { world. }\end{array}$ & I do it mental in my head. & $\begin{array}{l}\text { I ask my teacher, and } \\
\text { sometimes she will help } \\
\text { me by explaining the } \\
\text { steps or tell me to ask } \\
\text { someone else. }\end{array}$ & $\begin{array}{l}\text { Yes, because it proves that } \\
\text { I can do it. }\end{array}$ \\
\hline Student 3 & $B$ 's \& $C^{\prime} s$ & $\begin{array}{l}\text { No, I don't like the math work } \\
\text { that we did. If we finished our } \\
\text { morning work, we could play } \\
\text { around the world and eat } \\
\text { pretzels - that's the only part } \\
\text { that I liked. }\end{array}$ & $\begin{array}{l}\text { I don't. I can't. Well, } \\
\text { Ineed help figuring out } \\
\text { the steps. }\end{array}$ & $\begin{array}{l}\text { I ask my teacher for help, } \\
\text { but she says to try a } \\
\text { different way. But I can't } \\
\text { remember the steps to } \\
\text { each of the different ways }\end{array}$ & $\begin{array}{l}\text { No, there's stuff that we } \\
\text { didn't even learn on the test. } \\
\text { I don't recognize a lot of the } \\
\text { problems that are on the test. }\end{array}$ \\
\hline Student 4 & $B$ 's \& $C$ 's & $\begin{array}{l}\text { Most of the time I didn't like } \\
\text { math because our teacher } \\
\text { wouldn't explain things } \\
\text { clearly - she would just } \\
\text { say-just because. If art was } \\
\text { involved or writing, I would } \\
\text { understand it better. }\end{array}$ & $\begin{array}{l}\text { When I solve math problems } \\
\text { I try to work it out as slowly } \\
\text { as I can on graph paper so } \\
\text { I can figure out the process. } \\
\text { My teacher tells us how to } \\
\text { do it - not step by step, but } \\
\text { how to solve the problem. }\end{array}$ & $\begin{array}{l}\text { I get extremely upset. } \\
\text { I usually ask my teacher, } \\
\text { but she explains the } \\
\text { problem the same way } \\
\text { she does in class and } \\
\text { I still don't understand it. }\end{array}$ & $\begin{array}{l}\text { Absolutely not! They are hard } \\
\text { for me because there are too } \\
\text { many different steps to } \\
\text { remember or too many } \\
\text { different kinds of problems } \\
\text { on the same test. I can't } \\
\text { remember them all. }\end{array}$ \\
\hline Student 5 & $A ' s \& B$ 's & $\begin{array}{l}\text { Yes, my teacher is awesome. } \\
\text { She makes math class fun by } \\
\text { making up games (she tells us } \\
\text { she stays up to } 4: 00 \text { am to } \\
\text { make math games for us.) }\end{array}$ & $\begin{array}{l}\text { Pretty simply, I understand, } \\
\text { plan, solve, and check. }\end{array}$ & $\begin{array}{l}\text { She makes small groups } \\
\text { and helps us with what } \\
\text { we don't understand. }\end{array}$ & $\begin{array}{l}\text { Yes, they make me smarter. } \\
\text { I do well on them and I know } \\
\text { what to do. }\end{array}$ \\
\hline
\end{tabular}


Table 2.

NCTM standards reached through creative activities.

\begin{tabular}{|c|c|c|}
\hline NCTM Standard & Grade Level & Activity \\
\hline $\begin{array}{l}\text { Number and Operations } \\
\text { - } \quad \text { Understand numbers, ways of representing numbers, relationships among numbers, and number system } \\
\text { - } \quad \text { Understand meanings of operations and how they relate to one another } \\
\text { - } \quad \text { Compute fluently and make reasonable estimates } \\
\text { Problem Solving } \\
\text { build new mathematical knowledge through problem solving; } \\
\text { - } \quad \text { solve problems that arise in mathematics and in other contexts; } \\
\text { - } \quad \text { apply and adapt a variety of appropriate strategies to solve problems; } \\
\text { monitor and reflect on the process of mathematical problem solving }\end{array}$ & $\begin{array}{l}\text { Kindergarten } \\
\text { Student } \\
\text { (K-2 }{ }^{\text {nd }} \text { Grade } \\
\text { NCTM Standards) }\end{array}$ & $\begin{array}{l}\text { Cookie Division } \\
\text { Figure } 1\end{array}$ \\
\hline $\begin{array}{l}\text { Geometry } \\
\text { - Analyze characteristics and properties of two- and three-dimensional geometric shapes and develop } \\
\text { mathematical arguments about geometric relationships } \\
\text { - Specify locations and describe spatial relationships using coordinate geometry and other representation- } \\
\text { al systems } \\
\text { - Use visualization, spatial reasoning, and geometric modeling to solve problems }\end{array}$ & $\begin{array}{l}\text { Third Grade Stu- } \\
\text { dent } \\
\left(3^{\text {rd }}-5^{\text {th }} \text { Grade }\right. \\
\text { NCTM Standards })\end{array}$ & $\begin{array}{l}\text { Puppy Theme } \\
\text { Park } \\
\text { Figures } 2 \& 3\end{array}$ \\
\hline $\begin{array}{l}\text { Concepts of Number } \\
\text { - Understand numbers, ways of representing numbers, relationships among numbers, and number system } \\
\text { - } \quad \text { Understand meanings of operations and how they relate to one another } \\
\text { - } \quad \text { Compute fluently and make reasonable estimates }\end{array}$ & $\begin{array}{l}\text { Fourth Grade } \\
\text { Student } \\
\left(3^{\text {rd }}-5^{\text {th }} \text { Grade }\right. \\
\text { NCTM Standards })\end{array}$ & $\begin{array}{l}\text { Multiplication } \\
\text { Boards } \\
\text { Figures } 4 \text { \& } 5\end{array}$ \\
\hline $\begin{array}{l}\text { Measurement } \\
\text { - } \quad \text { Understand measurable attributes of objects and the units, systems, and processes of measurement } \\
\text { - } \quad \text { Apply appropriate techniques, tools, and formulas to determine measurements }\end{array}$ & $\begin{array}{l}\text { Sixth Grade Stu- } \\
\text { dent } \\
\left(6^{\text {th }}-8^{\text {th }} \text { Grade }\right. \\
\text { NCTM Standards })\end{array}$ & $\begin{array}{l}\text { Bench Assess- } \\
\text { ment Activity }\end{array}$ \\
\hline $\begin{array}{l}\text { Data Analysis and Probability } \\
\text { - } \quad \text { Formulate questions that can be addressed with data and collect, organize, and display relevant } \\
\text { data to answer them } \\
\text { - } \quad \text { Select and use appropriate statistical methods to analyze data }\end{array}$ & $\begin{array}{l}\text { Seventh Grade } \\
\text { Student } \\
\left(6^{\text {th }}-8^{\text {th }} \text { Grade }\right. \\
\text { NCTM Standards })\end{array}$ & $\begin{array}{l}\text { Gatorade Expe- } \\
\text { riment }\end{array}$ \\
\hline $\begin{array}{l}\text { Problem Solving } \\
\text { - } \quad \text { build new mathematical knowledge through problem solving; } \\
\text { - } \\
\text { - } \\
\text { - }\end{array}$ & $\begin{array}{l}\text { Kindergarten } \\
\text { Students } \\
\text { (K-2 }^{\text {nd }} \text { Grade } \\
\text { NCTM Standards) }\end{array}$ & $\begin{array}{l}\text { Human Game } \\
\text { Board } \\
\text { Figure } 6\end{array}$ \\
\hline $\begin{array}{l}\text { Measurement } \\
\text { - } \\
\text { - } \\
\text { - } \\
\text { Anderstand measurable attributes of objects and the units, systems, and processes of measurement } \\
\text { - } \\
\text { build new mathematical knowledge through problem solving; } \\
\text { - } \\
\text { solve problems that arise in mathematics and in other contexts; } \\
\text { apply and adapt a variety of appropriate strategies to solve problems }\end{array}$ & $\begin{array}{l}\text { Kindergarten } \\
\text { Students } \\
\text { (K-2 }^{\text {nd }} \text { Grade } \\
\text { NCTM Standards })\end{array}$ & Catapult \\
\hline
\end{tabular}

Upon reflection on these children's thoughts and feelings about their math education, it is striking how much insight these students seem to have into the research surrounding effec- tive math education. The students realize there has to be more to math than answering a problem correctly and they understand how art, games, and writing would help to increase their 
mathematical understanding. This same concept is supported in the literature surrounding effective mathematics instruction (Tsao, 2005; Wallace, Abbott, \& Blary, 2007; Kamii, 1999; 2000). Math involves more than following directions and requires multiple strategies for all students to reach their mathematics potential. Students communicated that following directions did not necessarily mean mastery of a math concept. They felt the need to experiment, brainstorm, and develop problem solving strategies of their own. These few students share the view of many American school students (Tsao, 2005) and realize the traditional mathematics model used in most of their schools of lecture, memorization, workbook practice, and testing needs revised to incorporate creative problem solving strategies.

Children benefit from a creative, autonomous problem solving approach to contextual problems (Kamii, 1999; 2000). The students interviewed with lower grades could not apply a learned algorithm in a new situation or in context when presented with new problems on a test. In order to develop transference of their skills, they need opportunities to present ideas, develop their own algorithms, and explore possibilities and solutions. Teachers can facilitate this through games, conversations, debate, and play/exploration (Kamii, 1999; 2000).

Conversation and debate offer unique insights into the child's thought process and construction of concepts and content. This can be facilitated by posing a problem and asking children for solutions (not answers, but strategies for a solution). When a solution is presented, other children can be encouraged to accept the solution, offer one of their own, and/or respectfully debate the other child's thought process. These strategies encourage reflection and create an autonomous environment for creating and experimenting with algorithms and problem solving strategies.

Play and exploration invite participation in physical-knowledge activities (Kamii, Miyakawa, \& Kato, 2007). These activities encourage the child to explore blocks, levers, patterns, pendulums, water, sand, indoor and outdoor materials and to develop their own problems and solutions with those materials. Time for exploration is a critical component of an autonomous mathematics classroom. Traditional scheduling and formats may need restructured in order to accommodate the needs of the creative problem solver. Often, debate and conversation can be incorporated into play and exploration experiences.

In a kindergarten classroom, a teacher is hit in the back of the head with a tiny plastic doll. She turns to find children in the block area constructing catapults and launching tiny figures over the book shelf. She observes and listens to their conversations about the catapult construction. While the room was too small to safely launch figures over the bookshelf, the teacher asks students to gather their materials and leads the students towards a gymnasium where they can experiment freely. She provides students with measurement devices and asks students to record their estimation and measurement data. She also asks students to draw designs of effective and ineffective catapults. Students explored materials, discussed and debated designs, and tested their designs through estimation and measurement. In this scenario, the kindergarten teacher recognized a wonderful opportunity to develop problem solving skills by recognizing the benefits of play and exploration and encouraging debate and discussion.

\section{Curricular Considerations}

Each activity presented in this paper addresses content-specific standards outlined by the National Council for the Teaching of Mathematics (See Table 2). While these content specific standards can be addressed in many ways in the classroom, each of the projects mentioned help facilitate the Representation, Communication, Reasoning and Proof, and Connection Standards listed as well. These standards are often overlooked in the classroom, but integrating the arts and facilitating creative problem solving skills invite these applications and synthesizing standards. It is through application and synthesis of math concepts that ideas can be challenged, created, and improved. Traditional tests may demonstrate standard content knowledge, but integrated projects inspire new applications and new possibilities.

In reflecting on the strategies presented in this paper, one wonders if the children interviewed would have different answers and attitudes if the arts were integrated into their mathematics classroom. Not every child loves math, music, art, drama or industrial arts, however most children like one of these. When that interest or talent is accessed, it can provide a tool for developing challenging and disinteresting concepts (Gardner, 2006).

If teachers of mathematics continue to teach what they know and ask students to memorize and regurgitate it, how can one ever expect any advancements to be made in math, engineering, science, technology or business? Integrating the arts into the mathematics classrooms provides students access to content, multiple perspectives on a topic, and invites them to think, apply, understand, create, and participate in their learning. It is in this participation that new ideas emerge and become possible. Math education requires restructuring to promote an autonomous classroom that facilitates creativity through the arts and creative problem solving to effectively prepare children for the economic, environmental, and humanitarian challenges of the new century (Sheridan-Rabideau, 2010). The restructuring efforts should be at the forefront of education policy and reform and should include teacher education, scheduling, curricular, and environmental strategies that support creativity in the mathematics classroom. As Short (Short, Kauffman, \& Kahn, 2000) suggests, "In their lives outside of school, children naturally move between art, music, movement, mathematics, drama, and language as ways to think about the world. It is only in schools that students are restricted to using one sign system at a time."

\section{References}

Armstrong, T. (2010). Neurodiversity: Discovering the extraordinary gifts of autism, ADHD, dyslexis, and other brain differences. Cambridge, MA: Da Capo Press.

Christensen, C., Johnson, J., \& Horn, M. (2008). Disrupting class: How disruptive innovation will change the way the world learns. New York, NY: McGrawHill.

Gardner, H. (1993). Frames of mind. New York: Perseus Books.

Gardner, H. (2006). Multiple intelligences: New horizons in theory and practice. New York: Perseus Books.

Gardner, H. (2009). Five minds for the future. Boston, MA: Harvard Business School Publishing.

Hardesty, L. (2008). The geometry of sound. Technology Review, 111, m7. Retrieved from ttp://www.technologyreview.com/ 
Harris, M. (2008). The effects of music instruction on learning the Montessori classroom. Montessori Life: A Publication of the American Montessori Society, 20, 24-31. Retrieved from http://www. amshq.org/publications.htm

Hirsh, R. (2004). Early childhood curriculum: Incorporating multiple intelligences developmentally appropriate practice, and play. Boston: Allyn \& Bacon.

Hope, S. (2010). Creativity, content, and policy. Arts Education Policy Review, 111, 39-47. doi:10.1080/10632910903455736

Isenberg, J., \& Jalongo, M. (2010). Creative thinking and arts-based learning: Preschool through fourth grade. Upper Saddle River, NJ: Pearson.

Ivcevic, Z. (2009). Creativity maps: Toward the next generation of theories of creativity. Psychology of Aesthetics, Creativity, and the Arts, 3, 17-21. Retrieved from http://www.apa.org/pubs/journals/ aca/index.aspx

Jensen, E. (2005). Teaching with the brain in mind, $2 e$. Alexandria, VA: Association for the Supervision of Curriculum Development.

Jensen, E. (2001). Arts with the brain in mind. Alexandria, VA: Association for the Supervision of Curriculum Development.

Kamii, C. (1999). Young children reinvent mathematics: Implications of Piaget's theory, $2 e$. New York, NY: Teachers College Press.

Principles and standards for school mathematics. (2000). Reston, VA: National Council for the Teaching of Mathematics.

Kamii, C., Miyakawa, Y., \& Kato, T. (2007). Trying to make a lever work at ages 1 to 4: The development of "functions" (logico- mathematical thinking). Early Education and Development, 18, 145-161.

National Education Association. (2004). No subjects left behind? Think again. National Education Association Today, 23, 26-27. Retrieved from: http://www.nea.org/neatoday/

Oberman, I. (2008). Waldorf education and its spread into the public sector. Encounter, 21, 10-14. Retrieved from http://www.great-ideas. org

Rauscher, F., \& Shaw, G. (1998). Key components of the Mozart effect. Perceptual and Motor Skills, 86, 835-841. Retrieved from http:// www.ammonsscientific.com/AmSci/

Royal, K. (2007). Mind, music, \& math. Direct Administration, 43, 18. Retrieved from http://www.districtadministration.com/

Schattschneider, D. (2006). Math and art in the mountains. The Mathematical Intelligencer, 28, 31-37. doi:10.1007/BF02986882

Sheridan-Rabideau, M. (2010). Creativity repositioned. Arts Education Policy Review, 111, 54-58. doi:10.1080/10632910903455876

Short, K. G., Kauffman, G., \& Kahn, L. H. (2000). I just need to draw: Responding to literature across multiple sign systems. The Reading Teacher, 54, 160-71

Simonton, D. (2000). Creativity: Cognitive, personal, developmental, and social aspects. American Psychologist, 55, 151-158.

doi:10.1037/0003-066X.55.1.151

Sloboda, J. (2001). Emotion, functionality, and the everyday experience of music: Where does music education fit? International Research in Music Education Conference, England: Exeter University.

Steiner, R. (1996). The education of the child: and early lectures on education. New York, NY: Anthroposophic Press.

Sternberg, R. (2006). Arts at the core: How six school districts integrate arts education into the curriculum. American School Board Journal, 193, 44-47. Retrieved by http://www.nsba.org

Tsao, Y. (2005). A comparison of american and taiwanese students: Their math perception. Journal of Instructional Psychology, 31, 206-213.

Wallace, A., Abbott, D., \& Blary, R. (2007). The classroom that math built: Encouraging young mathematicians to pose problems. Young Children, 62, 42-49.

Wilson, H. (2009). The Picasso in your classroom: How to meet the needs of talented artists in elementary school. Gifted Child Today, 32, 36-45. Retrieved form http://www.prufrock.com/ 